\title{
Scales, interaction and movement in later Mediterranean prehistory
}

Book or Report Section

Accepted Version

Chapman, R. (2014) Scales, interaction and movement in later Mediterranean prehistory. In: Souvatzi, S. and Hadji, A. (eds.) Space and Time in Mediterranean Prehistory. Routledge Studies in Archaeology. Routledge, New York and London, pp. 32-48. ISBN 9780415837323 Available at http://centaur.reading.ac.uk/39244/

It is advisable to refer to the publisher's version if you intend to cite from the work. See Guidance on citing.

Publisher: Routledge

All outputs in CentAUR are protected by Intellectual Property Rights law, including copyright law. Copyright and IPR is retained by the creators or other copyright holders. Terms and conditions for use of this material are defined in the End User Agreement. 


\section{www.reading.ac.uk/centaur}

\section{CentAUR}

Central Archive at the University of Reading

Reading's research outputs online 


\title{
CHAPTER
}

\section{SCALES, INTERACTION AND MOVEMENT IN LATER MEDITERRANEAN PREHISTORY}

\author{
Robert Chapman
}

\section{Introduction}

Some recent interpretations of later Mediterranean prehistory have prioritized the roles of cultural practices in the maintenance and change of social relations in time and space. There is talk of social identities, the importance of social memory, and the experience of landscapes in the daily lives of people (e.g. Van Dommelen and Knapp 2010). Time and space are seen less as archaeological frameworks than means by which people construct social relations and understand culturally the world in which they live and how they came to be where they are. These cultural practices are argued to have occurred at different scales, from days to centuries and from the household to the Mediterranean basin as a whole.

In this chapter my concern is with the main scales of time and space within which Mediterranean archaeologists have worked, how these scales have been constructed and are used by these archaeologists, what the deficiencies of such scales (as we know them) might be, and what theoretical assumptions (e.g. dynamic as opposed to static societies, isolated as opposed to connected social and political 
groups, top-down rather than bottom-up analyses of social reproduction) lie behind archaeological research. Given the size of the Mediterranean basin $(22,000$ miles from Jerusalem to Gibraltar, that is three months sailing before modern times) I am selective in the examples I use. The resolution of both spatial and temporal scales, as we currently know them, has implications for our understanding of social, political and economic changes at critical points in the prehistory of the Mediterranean from the adoptions of agriculture to the emergence of institutionalized inequalities.

\section{Dynamic and static societies in the Mediterranean}

Horden and Purcell (2000: 467) criticize historians and ethnographers for their emphasis on the 'timeless' nature of Mediterranean societies, by which rural societies are viewed as survivors from the past: static, traditional and isolated. Mediterranean ethnographers have given the impression that at least some Mediterranean societies have been frozen in time and cut off from the wider world and their study has emphasised "all that is archaic, culturally and economically primitive" (2000: 487). Such an approach creates a 'homogenised' (2000: 487) and 'Romantic' (2000: 28-9) view of Mediterranean societies, in which the past lives on in the present. Thus the historian Fernand Braudel (1972: 1239) wrote that “antiquity lives on round today's Mediterranean shores". This survivalism incorporated ahistorical stereotypes of 'traditional' rural economies (with transhumance and redistribution as necessary adaptations to environmental constants), along with dichotomies of agricultural/pastoral, mountain/lowland and town/rural societies, as well as 'prime'/'marginal' environments. 
Archaeological research on the later prehistoric Mediterranean in the first half of the twentieth century integrated this survivalism with a further dichotomy between the dynamic societies of the east (the sources of both agriculture and civilization) and the static societies of the west (which received economic and technological innovations through diffusion across a unifying sea). Individual Neolithic and Bronze Age artefact types, monument types and symbols, as well as artefact assemblages, from 'nuclear areas' of the western Mediterranean were attributed to east Mediterranean 'colonists' or ‘influences' (see Chapman 1990: 19-30 for examples from Iberia), and thereby the principles of cross-dating and association were used to extend the absolute chronology of the ancient Near East to Mediterranean and Temperate Europe. In many cases these artefact comparisons lacked ultimate conviction, while dating by the calibrated radiocarbon method established that specific artefacts and monuments in the west Mediterranean were earlier than their supposed prototypes in the east Mediterranean (Renfrew 1973).

As a result of the successful critique of diffusionism, greater emphasis was placed on autonomy in later prehistoric societies in all parts of the Mediterranean, but survivalism and the static/dynamic dichotomy continued to be in evidence. The Cambridge 'Palaeoeconomy' School emphasized long-term continuity in the relationship between people and Mediterranean environments, tracing seasonal movements between lowland and upland pastures in Greece, Italy and Iberia from the Middle Palaeolithic to the present day (Higgs 1975). The influence of Braudel's (1972) longue durée was visible in Barker's (1981) research on Neolithic and later societies in central Italy, with its emphasis on slow, minimal change among peasant 
farmers. Malone (2003: 299) follows this approach for Neolithic Italy as a whole by proposing that "once established as farming communities, the societies appear to be conservative, and often rather isolated, except through the exchange of exotica". In other studies, major changes in macro-variables such as population pressure or the intensification of production were needed to jerk life into such static systems. The major change seemingly came in the Bronze Age, but while 'civilization' emerged in the East, stratification and 'complexity' have been attributed to a very limited number of areas in the west Mediterranean before the development of the Etruscan state in the first millennium BC (see Chapman 2003 for discussion and examples). Mathers and Stoddart (1994: 16) even question the accuracy of the term 'stratification' for any prefirst millennium $\mathrm{BC}$ societies in the West.

\section{Fragmentation and Connectivity}

While the static/dynamic dichotomy has continued to shape archaeological assumptions on the Mediterranean past, the collapse of diffusionism encouraged archaeologists to explore both regional sequences of change and more localized networks of interaction over land and sea. One starting point was the Mediterranean itself.

There are a variety of criteria (e.g. geological, botanical, climatic, political) that are used to define the Mediterranean basin. The areas mapped by these criteria do not necessarily conform in their entirety, but the main object of debate concerns their boundaries. Horden and Purcell (2000: 80) criticize the notion that these boundaries 
are 'permanent' or 'uncrossable', referring to the Mediterranean as 'more softly edged'. In examining the geography of human history in the Mediterranean, these authors propose that "dense fragmentation complemented by a striving towards control of communications may be an apt summary of the Mediterranean past" (2000: 25). Although the fragmentary land masses and seas show a large degree of continuity through the postglacial past, they have been connected culturally in different ways at different moments in time. Degrees of isolation and connectivity have varied through time and were not subject to some form of constant environmental determinism.

This emphasis on autonomous development led archaeologists to explore regional sequences on land and the potential of islands to study how geographical isolation produced social and cultural idiosyncrasies. Such islands were viewed by some as closed 'laboratories' (Evans 1973), while others were more focussed on how such islands became colonised by human populations (e.g. Cherry 1981) and what networks of interaction existed at different times between islands and between islands and mainlands, from the local and regional scales to the entire Mediterranean basin. This focus on connectivity required greater attention to the potential and constraints of both the sea (e.g. visibility, winds, currents) and the islands (e.g. distance from land, area, diversity), within the contexts of changing sea levels and available maritime technologies. In addition to Cherry's (1981) use of the theory of island biogeography to analyze island colonisation across the Mediterranean, other authors have subsequently discussed the constraints of the sea on interaction, and the advantages of coastal navigation ('tramping') in areas like the west Mediterranean (Chapman 1990: 260-63), the Aegean (Broodbank 2000 on 'islandscapes'), the east Mediterranean (Manning and Hulin 2005) and right across the Mediterranean from 
east to west, as in the case of Phoenician colonisation in the early first millennium BC (Aubet 2001).

In addition to the study of the potential for, and constraints on, interaction over the sea, others have focussed on the characterisation of raw materials to trace the production sources and spatial movement of artefacts. These range from the Neolithic of the Aegean (Perlès 1992) and the central Mediterranean (e.g. Tykot 1996; Malone 1985), to the trans-Mediterranean trade of the Mycenaeans (e.g. Harding 1984; Vianello 2005) in the late second millennium BC and the Phoenicians in the early first millennium BC (Aubet 2001). Interpretations of this interaction vary from localized exchange designed to establish and maintain social relations, through use of exotic materials/artefacts to gain political advantage (the model of Helms 1988), to the political strategies of expanding state societies. Such inferences face the challenges of moving from evidence of the exchange of individual materials/artefacts to the reconstruction of exchange networks, and of grasping the full scale of interaction, even among early states, given the biased nature of the archaeological record (e.g. Manning and Hulin 2005: 283-84 on the small scale of Late Bronze Age Aegean imports in the east Mediterranean).

Two examples illustrate how our ideas about insularity have been challenged. Robb (2001) argues that Malta's cultural isolation during the periods of temple building and rebuilding (c. $3600-2400 \mathrm{BC}$ ) has been over-stated, given (a) the evidence for raw materials and goods (e.g. flint, obsidian, stone axes and amulets, lava, alabaster, red ochre, timber) introduced from Sicily (although see Malone and Stoddart 2004: 96), (b) the ability to cross from Sicily to Malta in 1-3 days in the 
summer, (c) the greater challenges of overland movement on Sicily as opposed to the sea crossing between southeast Sicily and Malta (see Robb 2001: Fig 1), (d) examples of cultural trends on Malta (e.g. decreased obsidian, local pottery styles) being shared by southern Italy and Sicily, and (e) cultural similarities (e.g. standing stone circles, rock-cut tombs, hypogea and temples) between Malta, Sicily, southern Italy and Sardinia. These observations contrast with the model of periods of interaction and contact alternating with those of ritual and isolation (e.g. Stoddart et al. 1993). Instead of Maltese temples being the peculiar, material outcome of isolation, they are argued to have symbolized "the construction of cultural difference" (Robb 2001: 192).

Lull et al. (2002: 118-19) argue against the determining nature of insularity per se, and propose that "the social space of an island does not finish where its land ends, but integrates the surrounding sea as well". Thus "the perception of this space and the attitude of island societies towards the outside does not seem to be fixed but changes through time, due to different economic, social or political factors". Insularity is therefore 'most of all' a social rather than a natural construction, determined by both internal and external factors. This is shown by phases of 'increased interaction' (whether through population movement, exchange of material goods, or 'communication of information and values') on the Balearic islands (the Early Beaker phase c.2500-2000 BC, the increase in new settlement and burial structures c.1600 BC, and changes in settlements, production and ideology c.1200$850 \mathrm{BC}$ ). Interestingly the period of talaiot construction on Mallorca and Menorca (c.850-600/500 BC) shows little evidence of the overseas contacts and exchange that were an integral part of the Phoenician trade network that reached Ibiza by the midseventh century. The potential for extra-island contacts was not exploited by the main 
Balearic island populations. It is worth adding that, in the subsequent Post-talaiotic period, which lasted until the Roman conquest in the late second century $\mathrm{BC}$, the evidence for overseas interaction (e.g. Punic) increased again, so the construction of another, localised, monument type, the taulas of Menorca, did not take place in a context of isolation, as would be predicted by the island laboratory argument.

The authors of these two case studies concur in the view that insularity is a human 'construction'. Insularity is also viewed as a relative rather than an absolute condition. Specific island sequences are studied in terms of the interaction of internal and external factors. From this perspective, the 'isolated' study of islands, especially in the context of the Mediterranean as opposed to the Pacific Ocean (the latter is 70 times the size of the former - Anderson 2011: 157), needs to be replaced by a largerscale study of production and social reproduction over neighbouring land and water masses (islands and mainlands). Socially and politically determined periods of greater 'insularity' and 'isolation' are also known from some mainland areas, such as is seen for the Argaric group of the earlier Bronze Age in southeast Spain, as compared with the preceding Chalcolithic (Risch 2002).

Even at a superficial level, the relatively small distances between Mediterranean mainlands and islands and the material evidence of interaction and colonization support the inference of social networks of different scales that made isolation a relative and socially contingent condition.

\section{Mediterranean societies at the large-scale}


While a localized focus on social, economic and political development, coupled with the tracing of exchange networks, marked out many areas of the Mediterranean in the 1970s and 1980s, a distinct approach has maintained the need for its study at the large-scale. This owes its origin to world systems theory. In what follows I will give a critical outline of this approach, coupled with examples of its application to the Mediterranean.

The development of world systems theory by Wallerstein (1974) was concerned with the historical study of the rise of capitalism as a world economy, the main dynamic being the asymmetric relationship between the providers of staple goods and raw materials in the peripheral regions (e.g. through trading outposts, colonies) and the dominant consumers of these goods and materials in core regions such as western Europe. Wallerstein's model did not include the study of noncapitalist and non-state societies in their own terms. Such societies were not necessarily characterized by unequal exchange, or the movement of bulk goods, and Wallerstein's analysis of 'peripheral' societies denied their individual characteristics and histories, as well as any role in the development of 'cores'. These principal criticisms have led others, especially Chase-Dunn and Hall (for references, see Hall et al. 2011) to reframe 'world-systems theory' as 'world-systems analysis', an intellectual tool for a macro-scale study of how societies (and not just capitalist ones) interact with each other, and what the outcomes of that interaction might be. Peripheries are afforded a more active role, including resistance, in the development of the system, dominance by cores is not automatic (given technological capabilities and the extent of coercive powers), 'prestige' or 'luxury' goods are recognised as of 
greater importance than bulk goods for trade relations in non-capitalist societies, and there are cycles of expansion and contraction in the dominance of cores and the extent of world systems (e.g. Frank 1993).

Archaeologists have engaged both positively and critically with the application of world-systems approaches to the material remains of past societies. Stein (1999) criticizes the basic assumptions of Wallerstein's model (e.g. 'core dominance, asymmetric exchange, and long-distance exchange as the prime movers of social change'), and takes Chase-Dunn and Hall to task that, "in attempting to generalize the applicability of the model while retaining its original terminology, they have eliminated its specificity as an explanatory construct and reduced the term "world-system" into little more than shorthand for "interregional interaction system"" (1999: 25), for which he proposes alternative models. McGuire (2002: 79) criticizes archaeological proponents of world-systems theory in North America for presenting "an economic reading of the old notion of interaction spheres". Among other criticisms, he notes that most archaeological applications of world-systems theory in north America have been "stripped of its Marxist foundation", inter-regional variations in 'cores' and 'peripheries' have been ignored, economic centrality may not equate with social or political centrality and that social change occurs at different scales and not just from the top down (2002: 137-8). Among Kohl's (2011) 'deficiencies' of the world-systems model are its 'terminological opacity'; the examples of multiple, rather than single, cores ("loosely integrated or overlapping") in contexts such as Sumer, Old Kingdom Egypt and Shang China; "eminently transferable and widely shared" (rather than capitalism's "monopoly of force based on both organizational and technological superiority") Bronze Age technologies; and the 
permeable boundaries of Bronze Age societies, as opposed to modern nation states. Kohl (2011: 83) accepts that there were "systemic, inter-regionally integrated networks of interaction" in the Bronze Age of western Eurasia, and changes in the boundaries of such interaction systems through time. Rather than stick to a rigid, world-systems model, he advocates the study of societies and cultures within larger “social fields of interaction”. Lastly McGuire (1989: 40) reclaims the Marxist basis of the world-systems model by using the concepts of production, distribution, exchange and consumption to analyse social reproduction within the context of larger scale systems of social, economic and political relationships - of particular interest are how relations of production, exchange and distribution lead to interdependencies between human communities and larger-scale groupings.

Archaeological applications of world-systems models to the later prehistory of the Mediterranean fit more broadly into the context of a European 'periphery' on the edge of a Near Eastern urban 'core', as can be exemplified in Sherratt's (1993) presentation of a Bronze Age world system (see especially his figure 13, for a schematic mapping of four stages of the expansion of core and periphery c.3500500BC, with the "urbanised manufacturing zone with bulk transport and state organization" reaching the Aegean by $1500 \mathrm{BC}$ and southern and eastern Spain by c.500 BC). A more detailed and theoretically explicit study is provided by Kristiansen (1998), who proposes the existence of a world-system of the Near East, the Mediterranean and Europe from c.2000 BC, while recognising that core-periphery relations differed between ancient and capitalist contexts. This "interpretive and explanatory sketch" (1998: 41), ultimately based on 1970s French structural-marxism, focuses on social reproduction operating at a larger, and more uncontrollable, scale 
(both temporal and spatial) than that of people's everyday lives, and foregrounds the study of the ways in which "the expansion of international exchange accelerated the pace of change in regional cultural traditions and -by the very nature of bronze technology - created a dependency in terms of supplies of metal and know-how between different regions that added a new dimension to change and tradition"” (1998: 3). The Mycenaeans are accorded a central role as "transmitters and receivers of new influences between the east Mediterranean and central Europe" (1998: 361) and the establishment of trade contacts with the West Mediterranean.

Parkinson and Galaty (2009a) highlight the diversity of opinions on the utility of the world-system/core-periphery approach to the Bronze Age in the eastern Mediterranean, and particularly for our understanding of the emergence of Minoan and Mycenaean societies on Crete and the Greek mainland in the context of interaction with pre-existing state and urban societies in the Near East. The editors (Parkinson and Galaty 2009b: 9) criticize world-systems analysis for its "broad brush lumping perspective that masks socio-cultural variability", arguing that the macroand long-term scales of analysis do not account for the archaeological record of change as seen in medium and local/short-term scales of analysis. When it comes to the nature of the archaeological evidence for interaction between the Near East and the Aegean Bronze Age, debate centres on (a) the amounts of such evidence and its rates of deposition (e.g. Cline 2011 on uneven rates of deposition, as opposed to an averaging out of imports across six centuries) and (b) the weight that should be placed on what Sherratt (2011: 91) calls 'known unknowns', that is goods and materials that survive poorly or not at all. Clearly we need to examine critically the evidence for interaction that is known, as well as potentially unknown, but this still leaves us with 
an interpretive problem, that is the role of this interaction in local social, political and economic change. Thus from the Cretan evidence, Cherry (2011: 138) takes a 'minimalist view' of Near Eastern trade, that this interaction occurred, but did not cause the emergence of Minoan palaces and states.

The distinction between material evidence for interaction and the causes/effects of that interaction is also raised for the West Mediterranean by the finds of Mycenaean, Cypriot and possibly Minoan imports (mostly pottery) from the seventeenth (Middle Helladic III) to the early eleventh (Late Helladic IIIC2) centuries BC. Blake (2008) and Vianello (2005) detail the nearly one thousand sherds from ninety-four sites from the (mainly southern and central) Italian peninsula, Sicily (and adjacent islands), Sardinia and southern Spain, although pottery is not evenly distributed across this large distance throughout the at least six centuries of its production (whether Aegean or local), distribution and consumption. A model of long-distance maritime trade has been preferred by some (e.g. Smith 1987; Kristiansen 1998), thus placing the west Mediterranean on the 'periphery' of the Aegean Bronze Age 'core', with the latter on the periphery of the Near Eastern core, and giving this interaction a primary role in the emergence of greater social complexity in the central Mediterranean.

This model is increasingly difficult to sustain, given analysis of the empirical record: there is no evidence for trading posts, nor for traders from the east Mediterranean; even allowing for the variable quality of the contextual and published evidence for pottery imports in the central Mediterranean, the majority of Italian Later Bronze Age sites in Italy lack imported Mycenaean pottery, and where it does occur, 
it is mostly in small numbers; and a majority of the 'Mycenaean' pottery was locally produced in Italy and Spain (Blake 2008). The numbers of copper oxhide ingots in Sardinia are only $10 \%$ of those found in the Uluburun wreck off the southern coast of Turkey, while there is no reason for Mycenaean metallurgical interest in southern Italy (where copper ores are absent) and no evidence for such interest in central Italy (where ores were present, but Mycenaean imports were scarce). There is no analytical evidence for west Mediterranean copper sources being used to produce Mycenaean metal objects, and the oxhide ingots on Sardinia, for all the debates about their analysis and attribution to a Cypriot source, have no compositional affinities with local sources of copper. Two further points are of key importance against a core/periphery interpretation: first, the mass production of exported Mycenaean pottery, coupled with contextual evidence for variable access (e.g. domestic/burial deposition, intra-site distributions), argue against any kind of 'luxury' or 'prestige' value; secondly production of the pottery appears to have been decentralized in both the Aegean and the West Mediterranean (Blake 2008).

The outcome of this careful evaluation of the current evidence for interaction between the East and West Mediterranean basins during the second millennium BC also supports a minimalist interpretation, rather than structured exploitation by an Aegean core of a West Mediterranean periphery. The scale of interaction between the East and West Mediterranean basins in the second millennium BC was small, irregular, decentralised and cannot be accorded any primacy in subsequent, local social, economic and political changes. In all these characteristics, the interaction was incomparable to that seen from later Phoenician and Greek colonies (e.g. Aubet 2001). 
While world-systems approaches follow a logical argument that change in human societies occurs at a variety of scales, they are illogical in the ways in which their proponents often fail to build up scales of change and interaction in time and space through the practices of production, distribution, exchange and consumption that contribute to the reproduction of human societies. The West Mediterranean examples in particular show what can happen when what may seem satisfying and to be expected' at the large-scale is confronted with an empirical record that offers it unconvincing support. We need to be cautious and critical of large-scale interpretations that present patterns in the material evidence in time and space without an equally critical study of the empirical record, evaluating the significance, specificity and reliability of those patterns and the extent to which they articulate with local sequences of change. This is where we should be conducting a more detailed analysis of production and reproduction in time and space.

\section{Archaeological Structuring in Time and Space}

If we accept that there are multiple scales of analysis, then it follows that we need to structure our particular materials, and their contexts, in time and space and to understand the history and practice of such structuring. While there is a tradition of such practice in the Mediterranean since the late nineteenth century, it has been (and remains) demonstrably uneven in its resolution and this has profound implications for our interpretations. There are variations in the nature and intensity of archaeological research across the Mediterranean basin. Within mainland areas like Greece, Italy and 
Spain the intensity of fieldwork determines our uneven knowledge of site types and distributions, as well as regional sequences and knowledge of production, distribution, exchange and consumption. Field survey was begun about two decades later in Spain (1970s) than in Italy and Greece (1950s). Bronze Age settlement in the Spanish interior has only been intensively studied since the 1970s. The Later Bronze Age of northern Greece has become the basis of more intensive fieldwork about a century after the classic Mycenaean sites were excavated in the Peloponnese. The human occupation of Cyprus has been extended backwards by some four millennia during the last two decades. Early Neolithic open-air settlements in eastern Spain, representing the first two centuries of agricultural adoption, have only begun to be studied systematically in the last fifteen years. Ditched enclosures dating to the third millennium BC, in some cases (e.g. Valencina de la Concepción) of unexpectedly large sizes, have been the object of survey and excavation in southern Spain and Portugal during the last two decades, often discovered by a mixture of urban growth (leading to rescue excavations) and aerial photography. Flat Neolithic enclosures of the fourth millennium BC are also a new site type in Greece. In spite of archaeological fieldwork over nearly one hundred and fifty years, it appears as if we have barely touched the surface.

Relative chronologies of later prehistoric sites and materials in the Mediterranean basin began to be developed in areas such as Egypt (Flinders Petrie on the Predynastic sequence), the Aegean (Arthur Evans on Crete) and southeast Spain (the Siret brothers) in the late nineteenth and early twentieth centuries. Subsequent elaboration of the Cretan and Mainland Greece sequences has produced "an incredibly rich, dense, ad hoc, and arcane system for describing and demarcating the 
time frame of the Aegean Bronze Age" (Manning 2010: 12), with variations between sites and regions, and in rates of change of different artefact types. The dating sequence for the second millennium BC in the Aegean exceeds any other area and period of the later prehistoric Mediterranean in its intensity and detail. There are many areas for which a relative chronology is still being developed and regions for which whole occupation periods are poorly known (e.g. the Neolithic of La Mancha, or the earlier Bronze Age of the southwestern central plateau of Spain - see Chapman 2008). Three-Age periods such as the Chalcolithic in the West Mediterranean are still rarely divided beyond an Early-Middle-Late sequence. At the other end of the scale, but still rare, are refined, relative chronologies of human occupation, such as the daily, monthly, seasonal or annual practices inferred through micromorphological study of the wall and floor deposits at Çatalhöyük (Matthews 2005).

An archaeological, absolute chronology for the later prehistoric Mediterranean (and indeed for central, western and northern Europe) was devised in the early twentieth century by cross-dating from Egypt, using accepted imports or sometimes vaguer typological similarities of materials. The impact of radiocarbon dating in the last five decades has been dramatic, contested (e.g. the chronology for the eruption of the Santorini volcano ) and uneven, both in time and space. High precision tree-ring dating is rare. Inter-regional variations in the intensity of $\mathrm{C} 14$ dating are notable in every mainland: for example, four sites in the province of Almería (southeast Spain) have yielded more dates than all the sites together of the western Andalucían provinces of Cadiz, Seville and Huelva (García Sanjuán and Odriozola Lloret 2010), with the absolute dating of the Argaric Bronze Age in Almería, Granada, Murcia and Jaén contributing to the highest resolution second millennium BC sequence in the 
Iberia (Castro et al. 1993-94). Rates of agricultural colonization in the West Mediterranean, with their implications for our understanding of this process, depend on quality control of samples and their contexts (e.g. Zilhao 2011). Our understanding of the nature and rapidity of other major 'transitions' depends on such quality control, along with the detail and integrity of stratigraphic sequences. On Crete the structural remodelling of Knossos during the Protopalatial and Neopalatial occupations, coupled with the limited excavation areas and poor contextual information from 'transitional' phases (see Cherry 2011: 112) to Middle Minoan palatial society, make understanding of these phases and state origins a challenge. Critical assessment of radiocarbon dating for the transition from the Los Millares (Chalcolithic) to Argaric (Bronze Age) groups in southeast Spain (Lull et al. 2010) raises the possibility of a brief overlap, rather than a straight sequence. As in Crete, the resolution of the temporal sequence has implications for our understanding of degrees and rates of social, political and economic change.

The structuring of sites and materials in space uses an archaeological record of variable quality and intensity, itself the outcome of a research and fieldwork infrastructure that lacks uniformity both locally and regionally. Since the late nineteenth century the concept of stylistically coherent and bounded 'cultures' has been a basis for the spatial structuring of successive stages of regional sequences of European prehistory. Although there has been much debate over the meaning of these 'cultures' and their relationship to any kinds of ethnic groupings, there is still an argument that stylistic variation measures the extent of social interaction, and that social boundaries vary in their fixity according to the nature of social integration (see Parkinson 2006). In the Mediterranean basin, there are examples of 'cultures' or 
styles that have internal stylistic homogeneity and spatial boundaries (e.g. the Argaric group in southeast Spain c.2250-1550 BC as opposed to the Valencian and Manchegan Bronze Age groups to the north and north-west), but such mutually exclusive distributions are rarer than less clearly demarcated cultures/pottery styles (e.g. the Italian Neolithic pottery styles whose edges are more blurred, or in some cases largely absent as regional or local markers-see Robb 2007: 181). Bernbeck (2012) roots the origins of the concept of bounded cultures within the context of European colonialism, challenges the idea of "internally coherent, externally clearly demarcated identities" and proposes that "we should rather think of the social as a potentially limitless network of groups and individuals", for which he adopts the term of a 'multitude', which is fluid in composition and extent as well as spatial definition. This fluidity and flexibility is argued to have been a major obstacle to the emergence of any long-term, unequal social relations, especially through mobility. This is an interesting proposal for thinking about Neolithic societies, their spatial patterning and material representation.

\section{Different scales of movement in time and space}

The colonization of Mediterranean islands, coupled with the introduction of material objects and domesticated plants and animals into empty or previously colonised islands, required labour organisation and the maintenance of social networks to enable long-term reproductive viability. Coupled with the evidence of agricultural settlement and adoption on the Mediterranean mainlands of Greece, Italy and Iberia, there is a strong argument for 'pioneer colonization' (e.g. Zilhao 2001), rather than continuous 
expansion in an east-west direction, with choice of the main settled areas related to basic, material conditions of existence (e.g. land cultivable with a digging stick technology, access to stone tools and raw materials for daily existence, sufficient areas of pasture, as well as wild plant and animal resources). Where these conditions, recognised in cultural traditions, were not present in sufficient frequencies (e.g. the near absence of metamorphic rock for stone axe production in the Balearic islands, where settled agricultural colonisation took place three millennia after that on the adjacent mainland of eastern Spain- Risch 2011), colonization was delayed. Even allowing for the time taken to expand and maintain social networks on mainlands and between mainlands and islands, as well as the organization of colonization in the contexts of local production and reproduction, the speed of movement was still $5 \mathrm{kms}$ per year, over 10 generations, from northern Italy to Portugal. Within and between these mainland and island areas, there was an increase in the movement of objects of social value, as seen through characterisation studies.

In local areas, movement of people would have taken place on daily, weekly, seasonal, annual and generational timescales. These movements would have varied in terms of involvement (which people?), distances moved, repetitiveness (always the same people?) and permanence. If we start with the agricultural system (and I do not imply that there was a uniform 'Mediterranean' system in the Neolithic), how intensive or extensive was it, and to what extent did it require mobility? What was the degree of this mobility, and how many people in the community were involved in it? What are the implications for the areas of land to which these early agricultural communities required inclusive or exclusive access? Where and how were the material objects required for daily existence produced in this space? How extensive 
were the networks of social interaction beyond the scale of individual communities (including periodic, short-term aggregations) that enabled the maintenance of social relationships and ultimately the reproduction of local societies?

These are all questions about landscapes of human movement and interaction. Although we have many characterisation studies of objects of social value (although not yet much evidence for the scale of movement of livestock), we have yet to undertake sufficient isotopic analyses to assess lifetime human movement and its scale (e.g. unpublished studies from Spain and Portugal for the third millennium BC Waterman, pers. comm.). For areas and periods where collective burial was practised, the assumption of collective lives needs systematic, isotopic testing. Human osteological studies from Bronze Age southeast Spain suggest the hypothesis of matrilocal residence in the Vera Basin (Buikstra and Hoshower nd). Degrees of sedentism associated with Neolithic communities and agricultural practices have still to be explicitly evaluated in the archaeological record (e.g. discussion in Chapman 2007 on southern Spain). Still rarer are models of what Neolithic agricultural systems would have looked like in space: Robb (2007: 100) studies the space required for basic productive activities in Neolithic villages in southern Italy, concluding that 'an intermarrying, stable demographic community would have utilized a minimum of between 80 and $200 \mathrm{~km}^{2}$, and maybe up to $400 \mathrm{~km}^{2}$, reconstructing some $20-50$ 'tribal groups over the Italian peninsula, Sicily and Malta (Robb 2007: 269).

We must be careful not to assume that these were stable, unchanging human landscapes. There were examples not only of the expansion and contraction (spatially and with altitude) of settled areas in the landscape, but also of settlement aggregation 
(e.g. the Neolithic ditched enclosures of the Tavoliere, and third millennium BC sites like Marroquiés Bajos and Valencina de la Concepción in southern Spain, which reached up to 400 hectares in size) and dispersal over periods of several hundred years.

\section{From small- to large-scales: a materialist approach}

Students of Mediterranean history and culture have struggled to escape dichotomous thought and to analyse their objects of study at different scales of time and space. Notions of static survivalism, especially in rural as opposed to urban areas across the basin, and of a dynamic East as opposed to a static West Mediterranean, still lie below the surface of archaeological thought. The radiocarbon revolution of the 1960s stimulated a greater emphasis on regional sequences of autonomous social, economic and political development. Spatial connections were studied in terms of the characterisation of objects of social value and island colonization as evidence of population movement: this was more multi-directional, rather than the uni-directional, east-west movement of diffusionism. By the 1980s, large-scale study of the later prehistory of the Mediterranean basin had re-emerged in the form of world-systems theory/analysis. More recently, and following the stimulus of Horden and Purcell (2000) there has been greater emphasis on both fragmentation and connectivity in the Mediterranean, emphasising 'insularity' as a social construction, whether we are talking about islands, or social and political groupings. 
Archaeologists work with material evidence of past communities that varies in terms of its preservation and intensity of study, and we group this material (whether it be objects, sites etc.) together in temporal units (e.g. periods, relative and absolute chronologies, different scales from the seasonal and annual through several generations) and spatial units (e.g. houses, communities, 'cultures', regions, landmasses). These groupings are our constructions, but they are based upon an empirical reality. Their advantage is that they enable us to work at different scales. Their disadvantage is that they break up what is often a continuity of human action and movement in time and space. Diffusionism over-emphasized the degree, continuity and scale of this movement, while critics of this approach stressed fragmentation at the expense of connectivity.

While much current discussion in archaeology focuses on the lives of our prehistoric ancestors as culturally constituted (and I do not deny the role of the cultural and symbolic in everyday lives and across generations), the emphasis in this paper has been on how archaeology works. Using our groupings of material evidence in time and space, our first priority should be to study the production and reproduction of social life. It is one thing to make assertions of large-scale systems of such reproduction, but it is another to demonstrate the scale and extent of such systems through empirical analysis from the bottom up. We must also be wary of focussing on the cultural construction of memory, tradition, and identities when we do not understand the structures in which people lived. According to this materialist argument, the much-vaunted human agents produce and reproduce social life on the basis of their structural capacities, rather than negotiating their identities and daily lives in a structureless void. To paraphrase Marx and Engels, history cannot be 
created and culture cannot be lived without satisfying the basic material needs of life. These needs are met through mental and physical labour in the course of daily social practices and cultural life. Such practices and lives are best studied locally and contextually (e.g. what are the conflicting demands of different forms of production, how is labour divided?), working from the local to the regional level, and beyond.

\section{Acknowledgements}

I would like to thank Stella Souvatzi and Athena Hadji for their invitation to write this overview and for their advice on its content. I also thank Anna Waterman for discussing details of isotopic analyses of Copper Age burials in Spain and Portugal.

\section{Bibliography}

Anderson, A. 2011. Islands from the south. An Oceanic perspective on island colonisation. In N. Phoca-Cosmetatou (ed.) The First Mediterranean Islanders: Initial Occupation and Survival Strategies: 157-71. Oxford: University of Oxford School of Archaeology.

Aubet, M. E. 2001. The Phoenicians and the West. Politics, Colonies and Trade (Second Edition). Cambridge: Cambridge University Press.

Barker, G. 1981. Landscape and Society: Prehistoric Central Italy. London: Academic Press.

Bernbeck, R. 2012. Multitudes before sovereignty: theoretical reflections and a Late Neolithic case. In T. L. Kienlin and A. Zimmerman (eds.) Beyond Elites. Alternatives 
to Hierarchical Systems in Modelling Social Formations. Volume 1: 147-68. Bonn: Verlag Dr. Rudolf Habelt GmbH.

Blake, E. 2008. The Mycenaeans in Italy: a minimalist position. Papers of the British School at Rome 76: 1-34.

Braudel, F. 1972. The Mediterranean and the Mediterranean World in the Age of Phillip II. London: Collins.

Broodbank, C. 2000. An Island Archaeology of the Early Cyclades. Cambridge: Cambridge University Press.

Buikstra, J. E. and L. Hoshower n.d. Análisis de los restos humanos de la necropolis de Gatas.

Castro, P.V., Chapman, R. W., Gili, S., Lull, V., Micó, R., Rihuete, C., Risch, R. and M. E. Sanahuja 1993-94. Tiempos sociales de los contextos funerarios argáricos. Anales de Prehistoria y Arqueología 9-10: 77-105.

Chapman, R. 1990. Emerging Complexity. The Later Prehistory of south-east Spain, Iberia and the west Mediterranean. Cambridge: Cambridge University Press.

Chapman. R. 2003. Archaeologies of Complexity. London: Routledge. 
Chapman, R. 2008. Producing inequalities: regional sequences in later prehistoric Southern Spain. Journal of World Prehistory 21: 195-260.

Cherry, J. F. 1981. Pattern and process in the earliest colonisation of the Mediterranean islands. Proceedings of the Prehistoric Society 47: 41-68.

Cherry, J. F. 2011. Sorting out C rete's Prepalatial off-island interactions. In W. A. Parkinson and M. L. Galaty (eds.) Ancient State Interaction. The Eastern Mediterranean in the Bronze Age: 107-40. Santa Fe: School for Advanced Research Press.

Cline, E. H. 2011. Bronze Age interactions between the Aegean and the Eastern Mediterranean revisited: mainstream, periphery or margin? In W. A. Parkinson and M. L. Galaty (eds.) Ancient State Interaction. The Eastern Mediterranean in the Bronze Age: 161-80. Santa Fe: School for Advanced Research Press.

Evans, J. D. 1973. Islands as laboratories for the study of cultural process. In C. Renfrew (ed.) The Explanation of Culture Change: Models in Prehistory: 517-20. London: Duckworth.

Frank, A. G. 1993. The Bronze Age world system and its cycles. Current Anthropology 34: 383-413.

García Sanjuán, L. and C. Odriozola Lloret 2010. La cronología radiocarbónica de la Edad del Bronce (ca. 2200-865 cal ANE) en el Suroeste de la Península Ibérica. In J. 
Jiménez Ávila (ed.) Actas de la Reunión Sidereum Ana II: El Río Guadiana en el Bronce Final (Mérida, Mayo de 2008). Mérida: CSIC.

Hall, T. D., Kardulias, P. N. and C.Chase-Dunn 2011. World-systems analysis and archaeology: continuing the dialogue. Journal of Archaeological Research 19: 23379.

Harding, A. F. 1984. The Mycenaeans and Europe. London: Academic Press.

Helms, M. W. 1988. Ulysses’ Sail. An Ethnographic Odyssey of Power, Knowledge and Geographical Distance. Princeton: Princeton University Press.

Higgs. E. (ed.) 1975. Palaeoeconomy. Cambridge: Cambridge University Press.

Horden, P. and N. Purcell 2000. The Corrupting Sea. A Study of Mediterranean History. Oxford: Blackwell.

Kohl, P. L. 2011. World-systems and modelling macro-historical processes in later prehistory: an examination of old and a search for new perspectives. In T. C.

Wilkinson, S. Sherratt and J. Bennet (eds.) Interweaving Worlds. Systemic Interactions in Eurasia, c.7th to 1st Millennia BC: 77-86. Oxford: Oxbow Books.

Kristiansen, K. 1998. Europe Before History. Cambridge: Cambridge University Press. 
Lull, V., Micó, R., Rihuete, C. and R. Risch 2002. Social and ideological changes in the Balearic islands during later prehistory. In W. H. Waldren and J. A. Ensenyat (eds.) World Islands in Prehistory: 117-26. Oxford: British Archaeological Reports International Series 1095.

Lull, V., Micó, R., Rihuete, C. \& R. Risch 2010. Límites históricos y limitaciones del conocimiento arqueológico: la transicón entre los grupos arqueológicos de Los Millares y El Argar. In P. Bueno, Gilman, A., Martín Morales, C. and F. J. Sánchez Palencia (eds.) Arqueología, Sociedad, Territorio y Paisaje: 75-94. Madrid: Consejo Superior de Investigaciones Científicas.

Malone, C. 1985. Pots, Prestige and Ritual in Neolithic Southern Italy. In C. Malone and S. Stoddart (eds.) Papers in Italian Archaeology IV: The Cambridge Conference: 118-151. Oxford: British Archaeological Reports.

Malone, C. 2003. The Italian Neolithic: a synthesis of research. Journal of World Prehistory 17: 235-312.

Malone, C. and S. Stoddart 2004. Towards an Island of Mind. In J.F. Cherry, C. Scarre and S. Shennan (eds.) Explaining Social Change: 93-102. Cambridge: McDonald Institute for Archaeological Research.

Manning, S. W. 2010. Chronology and Terminology. In E. H. Cline (ed.) The Aegean Bronze Age (ca. 3000-1000 BC): 11-28. Oxford: Oxford University Press. 
Manning, S. W. and L. Hulin 2005. Maritime Commerce and Geographies of

Mobility in the Later Bronze Age of the Eastern Mediterranean: Problematizations. In E. Blake and A. B. Knapp (eds.) The Archaeology of Mediterranean Prehistory: 270302. Oxford: Blackwell.

Mathers, C. and S. Stoddart (eds.) 1994. Development and Decline in the Mediterranean Bronze Age. Sheffield: J. R. Collis Publications.

Matthews, W. 2005. Life-cycle and life-course of buildings. In I. Hodder (ed.) Catalhöyük perspectives. Reports from the 1995-99 seasons: 125-49. Cambridge: McDonald Institute for Archaeological Research/British Institute at Ankara.

McGuire, R. H. 1989. The greater Southwest as a periphery of Mesoamerica. In T.C. Champion (ed.) Centre and Periphery. Comparative Studies in Archaeology: 40-66. London: Routledge.

McGuire, R. H. 2002. A Marxist Archaeology. New York: Percheron Press.

Parkinson, W. A. 2006. Tribal boundaries: stylistic variability and social boundary maintenance during the transition to the Copper Age on the Great Hungarian Plain. Journal of Anthropological Archaeology 25: 33-58.

Parkinson, W. A. \& M. L. Galaty (eds.) 2009a. Ancient State Interaction. The Eastern Mediterranean in the Bronze Age. Santa Fe: School for Advanced Research Press. 
Parkinson, W. A. \& M. L. Galaty 2009b. Introduction. Interaction and Ancient Societies. In W. A. Parkinson and M. L. Galaty (eds.) Ancient State Interaction. The Eastern Mediterranean in the Bronze Age: 3-28. Santa Fe: School for Advanced Research Press.

Perlès, C. 1992. Systems of exchange and organization of production in Neolithic Greece. Journal of Mediterranean Archaeology 5: 115-64.

Renfrew, C. 1973. Before Civilisation. London: Jonathan Cape.

Risch, R. 2002. Recursos naturales, medios de producción y explotación social. Mainz am Rhein: Verlag Philipp von Zabern.

Risch, R. 2011. Social and economic organisation of stone axe production and distribution in the western Mediterranean. In V. Davis and M. Edmonds (eds.) Stone Axe Studies III: 99-118. Oxford: Oxbow Books.

Robb, J. 2001. Island identities: ritual, travel and the creation of difference in Neolithic Malta. European Journal of Archaeology 4(2): 175-202.

Robb, J. 2007. The Early Mediterranean Village. Agency, Material Culture and Social change in Neolithic Italy. Cambridge: Cambridge University Press. 
Sherratt, A. 1993. What would a Bronze Age world system look like? Relations between temperate Europe and the Mediterranean in later prehistory. Journal of European Archaeology 1.2: 1-58.

Sherratt, S. 2011. The Aegean and the wider world: some thoughts on a worldsystems perspective. In W. A. Parkinson and M. L. Galaty (eds.) Ancient State Interaction. The Eastern Mediterranean in the Bronze Age: 81-106. Santa Fe: School for Advanced Research Press.

Smith, T. R., 1987. Mycenaean Trade and Interaction in the West Central Mediterranean 1600-1000 BC. Oxford: British Archaeological Reports International Series 371 .

Stein, G. J. 1999. Rethinking World-Systems. Diasporas, Colonies and Interaction in Uruk, Mesopotamia. Tucson: University of Arizona Press.

Stoddart, S., Bonanno, A., Gouder, T., Malone, C. and D. Trump 1993. Cult in an island society: prehistoric Malta in the Tarxien period. Cambridge Archaeological Journal 3: 3-19.

Tykot, R. 1996. Obsidian procurement and distribution in the central and western Mediterranean. Journal of Mediterranean Archaeology 9(1): 39-82.

Van Dommelen, P. and A. B. Knapp 2010. Material Connections in the Ancient Mediterranean. Mobility, Materiality and Identity. London: Routledge. 
Vianello, A. 2005. Late Bronze Age Mycenaean and Italic Products in the West Mediterranean. A Social and Economic Analysis. Oxford: British Archaeological Reports International Series 1439.

Wallerstein, I. 1974. The Modern World-System: Capitalist Agriculture and the Origins of European World-Economy in the Sixteenth Century. New York: Academic Press.

Zilhão, J. 2001. Radiocarbon evidence for maritime pioneer colonization at the origins of farming in west Mediterranean Europe. Proceedings of the National Academy of Science USA 98: 14180-14185.

Zilhao, J. 2011. Time is on my side... In A. Hadjikoumis, E. Robinson and S. Viner (eds.) Dynamics of Neolithisation in Europe. Studies in Honour of Andrew Sherratt: 46-65. Oxford: Oxbow Books. 